\title{
BROŃ JĄDROWA W POLITYCE BEZPIECZEŃSTWA WYBRANYCH PAŃSTW
}

\begin{abstract}
ABSTRAKT: Broń jądrowa stanowi czynnik odstraszania militarnego, tym samym jest to środek kształtowania bezpieczeństwa oraz utrzymania równowagi strategicznej. Dlatego też, mimo przeciwdziałania rozprzestrzenianiu się broni jądrowej, nie ma politycznej woli, aby do jej wyeliminowania ostatecznie doprowadzić. Celem artykułu jest analiza i ocena wpływu broni jądrowej na kształtowanie bezpieczeństwa międzynarodowego. W artykule przyjęto, że broń jądrowa zarówno w kategoriach politycznych, jak i militarnych stanowi ważny czynnik kształtowania relacji międzynarodowych, dlatego też znaczenie broni jądrowej w relacjach międzynarodowych niewiele się zmienia mimo upływu czasu. Większość państw, które taką broń posiadają, modernizuje i rozwija swoje arsenały, widząc w tym nie tylko wyraz swojej potęgi lecz także gwarancje suwerenności i bezpieczeństwa. W ocenie autora studiowanie tego materiału powinno przynajmniej przywołać pewną refleksję nad rozwojem broni jądrowej jako środka kształtowania współczesnych relacji bezpieczeństwa.
\end{abstract}

SŁOWA KLUCZOWE: broń jądrowa, polityka bezpieczeństwa, użycie broni jądrowej, modernizacja sił jądrowych

\section{NUCLEAR WEAPONS IN THE SECURITY POLICY OF SELECTED COUNTRIES}

\begin{abstract}
Nuclear weaponry is a factor of military deterrence, hence is also a key means of shaping security and maintaining strategic balance. Therefore, despite implementation of the policy of a nuclear non-proliferation, there is no political will towards eliminating it completely and ultimately. The aim of the article is to analyze and assess the impact of nuclear weapons on shaping the international security policy. In the paper, the author assumed that nuclear weapons, in both political and military categories, are an important factor in shaping international relations. Therefore the importance of nuclear weapons in international relations, despite the passage of time, does not change much. Most countries that possess nuclear weapons, modernize and expand their arsenals, seeing in that not only an expression of power but also guarantee to its security. Studying the article should at least bring some reflection on the evolution of nuclear weapons as a mean of shaping contemporary security relationships.
\end{abstract}

KEYWORDS: nuclear weapons, security policy, use of nuclear weapons, modernization of nuclear forces

\footnotetext{
${ }^{1}$ WSB University in Dąbrowa Górnicza; Poland.
} 


\section{WPROWADZENIE}

Mimo upływu siedemdziesięciu lat od pierwszego użycia broni jądrowej, niezależnie od tragicznych skutków tego wydarzenia, wciąż nie traci ona na znaczeniu w światowej polityce. Co więcej, istnieje spora grupa państw aspirujących do jej posiadania. Korea Północna, do niedawna mało znaczący reżim totalitarny, za sprawą posiadania broni jądrowej stał się podmiotem politycznym, pozostającym w centrum uwagi światowych mocarstw: Stanów Zjednoczonych, Federacji Rosyjskiej, Chin, Japonii, a także Korei Południowej. Państwo to stawia twarde warunki negocjacyjne. Jej oczekiwania to cena, jaką Świat jest gotów ponieść za jej denuklearyzację. Oczekiwania są duże. Korea żąda zniesienia sankcji politycznych i gospodarczych, a co za tym idzie także pokrycia wszelkich kosztów socjalnej oraz polityczno-gospodarczej transformacji państwa. Broń jądrowa w ręku przywódcy Korei stanowi jedyną, ale bardzo mocną kartą przetargową. Jest to coś w rodzaju ,asa w rękawie”, o którym partnerzy nie wszystko wiedzą, ale muszą się z nim liczyć. Czyż nie jest to kusząca perspektywa także dla innych, równie politycznie awanturniczych państw?

Podobnie sprawy technologii jądrowej postrzega Iran, prezentując nowe stanowisko w tej sprawie $^{2}$. W to, że posiadanie broni jądrowej daje gwarancje bezpieczeństwa, nikt współcześnie nie wątpi. Niezależnie od tego, że niekiedy te gwarancje mogą być „kruche”. Posłużę się tu przykładem procesu denuklearyzacji Ukrainy. Za zwrot do Federacji Rosyjskiej arsenałów jądrowych, rozwiniętych na terytorium Ukrainy, podpisano tzw. Memorandum Budapesztańskie o mocy traktatu ${ }^{3}$. Miał on gwarantować Ukrainie suwerenność i integralność terytorialną. Warto zauważyć, że w 2014 roku, już po aneksji Krymu, Rosją odmówiła konsultacji w tej sprawie, a sygnatariusze traktatu, mimo wezwań Rady Najwyższej Ukrainy, nie wykazali oczekiwanego zdecydowania ${ }^{4}$. Można więc zadać sobie pytanie: co pozostało z międzynarodowych gwarancji? Niestety niewiele, pozostały działania dyplomatyczne, które nie mają wielkiej wartości $\mathrm{w}$ zderzeniu z groźbą realnego użycia broni jądrowej, pozostającej $\mathrm{w}$ dyspozycji zagrożonego państwa. Trudno ocenić, na jakie działania wobec Ukrainy odważyłaby się Rosja, gdyby miała świadomość, że dysponuje ona potencjałem nuklearnym, a przy tym jest zdesperowana zagrożeniem suwerenności. Pozostają spekulacje polityczne, bo brakuje innych przykładów, wskazujących na uwarunkowania posiadania i dobrowolnego pozbycia się broni jądrowej oraz wpływu tego aktu na dalszą politykę. Przykłady Korei i Iranu są jednak odmienne od sytuacji Ukrainy, nie dają zatem podstaw, aby je rozpatrywać łącznie.

\footnotetext{
${ }^{2}$ Władze Iranu nie wykluczają możliwości wypowiedzenia Układu o nierozprzestrzenianiu broni jądrowej (Nuclear Non-Proliferation Treaty - NPT) w razie zaostrzenia sankcji nałożonych na Teheran, jak oświadczył irański minister spraw zagranicznych, za: http://wgospodarce.pl/informacje/62980-iran-juz-gotowy-na-bombe-atomowa, (30.04.2019).

${ }^{3}$ Memorandum budapeszteńskie (Memorandum Budapeszteńskie o Gwarancjach Bezpieczeństwa) - porozumienie międzynarodowe niemające statusu traktatu podpisane w grudniu 1994 roku w Budapeszcie, na mocy którego Stany Zjednoczone, Rosja i Wielka Brytania zobowiązały się do respektowania suwerenności i integralności terytorialnej Ukrainy, oraz powstrzymania się od wszelkich gróźb użycia siły przeciwko jej niepodległości i integralności terytorialnej, a Ukraina zobowiązała się do przekazania strategicznej broni nuklearnej Rosji, za: https://pl.wiki pedia.org/wiki/Memorandum_budapeszteńskie, (30.04.2019).

${ }^{4}$ https://www.defence24.pl/memorandum-budapesztanskie-pozorna-gwarancja-bezpieczenstwa-dla-ukrainy, (30.04.2019).
} 
Celem niniejszego opracowania jest analiza relacji polityczno-militarnych w odniesieniu do broni jądrowej. W toku studiowania materiałów, już na wstępie do analizy, pojawiło się spostrzeżenie, że broń jądrowa była i jest nieodzownym elementem prowadzonej polityki, komponentem doktryn i strategii militarnych, a przede wszystkim strategicznym elementem odstraszania. Dlatego też naturalną konsekwencją rozważań autora było przyjęcie wyselekcjonowanych problemów badawczych, do których zalicza się: 1) Jakie jest miejsce i rola broni jądrowej w doktrynach państw ,atomowych”?, 2) Jakie są ograniczenia prawnomiędzynarodowe w zakresie użycia broni jądrowej?, 3) Dlaczego broń jądrowa pozostaje wciąż na tyle ,atrakcyjna”, że różne państwa prowadzą badania nad jej budową oraz rozwojem?

\section{KONCEPCJE WYKORZYSTANIA BRONI JĄDROWEJ W POLITYCE BEZPIECZEŃSTWA WYBRANYCH PAŃSTW}

Na szczycie NATO w Pradze, w 2009 roku, Prezydent Stanów Zjednoczonych Ameryki Północnej wypowiedział znamienne słowa: ,(...)zredukujemy znaczenie broni jądrowej w naszej strategii bezpieczeństwa narodowego i będziemy zachęcać innych do zrobienia tego samego"5. Cel tej wypowiedzi był taki, że: oto właśnie kończy się okres postrzegania bezpieczeństwa przez pryzmat posiadania broni jądrowej. Świat bez broni jądrowej, to świat - tak można założyć wolny od wszelkiego rodzaju zagrożeń płynących z samego jej istnienia. Prezydent Barack Obama składając historyczną deklarację chyba sam miał wątpliwości, co do jej realizmu, bo zaraz dodał, że realizacja tej wizji może potrwać dekady, ale jest możliwa do osiągnięcia. Niestety, wizja ta była iluzją, a może tylko PR-owską zagrywką nowo wybranego prezydenta aspirującego do Pokojowej Nagrody Nobla?

Najważniejsi aktorzy posiadający broń jądrową (głównie Federacja Rosyjska, bo to jej w największym stopniu dotyczyło to oświadczenie) potraktowała je jako polityczną naiwność, wykorzystaną przeciwko nowemu Prezydentowi, jak również Stanom Zjednoczonym. Minęło dziesięć lat, a polityka nuklearna - zarówno NATO, jak i Stanów Zjednoczonych oraz Federacji Rosyjskiej - niewiele się zmienia. Ponownie, jak w okresie zimnej wojny, w relacjach międzynarodowych służy politycznemu odstraszaniu oraz wzmacnianiu działań dyplomatycznych. Czyżby rysował się nowy wyścig zbrojeń? Zdaniem wielu analityków wojskowych, prawdopodobnie tak. Potwierdza to jednostronne zawieszenie od 2 lutego 2019 roku przez Stany Zjednoczone Układu o całkowitej likwidacji pocisków rakietowych pośredniego zasięgu (Treaty on Intermediate-range Nuclear Forces - INF). W następstwie tej deklaracji, to samo zrobiła Rosja, co stanowi początek końca traktatu, międzynarodowej kontroli rozprzestrzeniania się broni jądrowej rozmieszczanej na rakietach balistycznych średniego zasięgu (500-5500 km) w Europie ${ }^{6}$.

\footnotetext{
5 Za: S. Zarychta, Broń jądrowa w kształtowaniu bezpieczeństwa 1945-2015, Warszawa 2016; Vide: także http://www.politykaglobalna.pl, (20.03.2018).

${ }^{6}$ Traktat INF - podpisany przez prezydentów Ronalda Reagana i Michaiła Gorbaczowa w 1987 r., pozwalał wyeliminować ponad 2600 pocisków, zakończył też wieloletni wyścig zbrojeń na terenie Europy. Zamiar
} 
Władimir Putin w swoim orędziu wygłoszonym do obu izb parlamentu rosyjskiego w styczniu 2018 roku użył słów, które nie pozostawiają już żadnej wątpliwości: „Rosja rozpoczęła aktywną fazę testów nowej międzykontynentalnej rakiety balistycznej Sarmat. Nowa rakieta ma zastąpić najpotężniejszy dotąd rosyjski międzykontynentalny pocisk balistyczny Wojewoda"7. Putin stwierdził, że Rosja będzie podejmować dalsze kroki w odpowiedzi na rozwijanie amerykańskiego systemu obrony przeciwrakietowej. Nie uszło to uwadze kierownictwa NATO. Jens Stoltenberg na spotkaniu z prezydentem Andrzejem Dudą stwierdził, że: „Rosja jest gotowa i chce używać siły, aby zmieniać granice Europy”. Wygląda na to, że wyścig zbrojeń, który już trwa, wygrywa Rosja. Na jakąkolwiek, choćby symboliczną obecność sił NATO w państwach bałtyckich i Europy Środkowowschodniej Rosja odpowiada budową zgrupowań uderzeniowych wojsk w pobliżu zewnętrznych granic Sojuszu. Mimo pozorów politycznego dialogu (rozmowy Johna Kerry'ego z Siergiejem Lawrowem oraz Władimirem Putinem) tak napiętych relacji bezpieczeństwa nie było od połowy lat 80 . XX w. W wojskowej retoryce Federacji Rosyjskiej państwa NATO oraz Stany Zjednoczone stały się na nowo „bardzo prawdopodobnym przeciwnikiem”8. Wydawało się, że od czasu kryzysu kubańskiego w 1962 roku, kiedy to istniało rzeczywiste zagrożenie wybuchu konfliktu atomowego, doszło jednak do opamiętania i że: ,państwa atomowe nie prowadzą między sobą wojen”. Czy tak jest w istocie?

Nuklearne zagrożenie jest wciąż bardzo realne. Do grona państw posiadających nuklearny potencjał dołączyła Korea Północna i nie zamierza rezygnować z eksponowania swojej potęgi z racji posiadania broni jądrowej. Jak ostatnio zauważył Kim Dzong Un, przywódca Korei Północnej, jego państwo użyje broni atomowej przeciwko Stanom Zjednoczonym (lub innemu wrogiemu państwu) jedynie dla obrony swojego terytorium ${ }^{9}$. Nie ma więc mowy o istnieniu świata bez broni jądrowej, jak to kilka lat temu wyobrażał sobie prezydent Obama.

Po 1945 r. świat podzielił się w dwa przeciwstawne bloki polityczno-militarne, wykorzystujące swój potencjał jądrowy do odstraszania oraz wzajemnego politycznego oddziaływania na siebie. Spowodowało to, że broń jądrową zaczęto postrzegać jako skuteczną

wypowiedzenia traktatu INF Stany Zjednoczone wstępnie ogłosiły już w 2014r., zarzucając Rosji jego łamanie. Rozmowy z Rosją zakończyły się niepowodzeniem, bo Stany Zjednoczone domagały się zniszczenia pocisków manewrujących 9M729 (zdolnych do przenoszenia głowic jądrowych oraz konwencjonalnych) i ich wyrzutni. Rosja utrzymywała, że system ten jest zgodny z traktatem, ponieważ jego zasięg wynosi poniżej $500 \mathrm{~km}$. Rosja odmówiła jednak zaprezentowania pocisku do oceny przez zespół ekspertów. Przed upływem amerykańskiego ultimatum, 23 stycznia 2019 r., zademonstrowano wyrzutnie, pojemniki startowe oraz schematy funkcjonalne, ale bez pocisku. Działania te amerykanie uznali za niewiarygodne, propagandowe, zwłaszcza że zarzuty amerykańskie znane były już pod koniec 2017 r. Dodatkowo, za zawieszeniem traktatu przez Stany Zjednoczone przemawiał fakt, że sam traktat był nieskuteczny, bo ograniczał możliwości reagowania Stanów Zjednoczonych na zagrożenie ze strony Chin, które nie są stroną traktatu, a rozbudowują zakazany nim arsenał, stanowiąc rosnące zagrożenie dla USA, więc jego zawieszenie pozwoli przyspieszyć modyfikację istniejących oraz rozwinięcie nowych pocisków, dotychczas zakazanych obowiązującym traktatem, za: http://www.pism.pl/publikacje/komentarz/nr-10-2019 (3.05.2019).

7 Rosjanie ujawnili nową rakietę międzykontynentalną piątej generacji RS-28 „Sarmat”. Nowa rakieta balistyczna ma zastąpić pociski starszej generacji R-36M2 „Wojewoda” znane w NATO jako SS-18 Satan, http://www.space24.pl (20.03.2018).

${ }^{8}$ Za: Rosja gotowa do wojny nuklearnej. Putin straszy świat, www.geopolityka.pl (20.03.2018).

${ }^{9} 28$ listopada Korea Północna przetestowała pocisk balistyczny Hwasong-15. Ocenia się, że zasięg rakiety to 13 tysięcy kilometrów. To oznaczałoby możliwość osiągnięcia dowolnego celu na terenie kontynentalnej części USA, a także w Europie, www.independent.co.uk/us (20.03.2018). 
gwarancję bezpieczeństwa. Broń, która dodatkowo zwiększa rangę państwa na arenie międzynarodowej, stanowi przy tym swoistą polisę ubezpieczeniową na wypadek wzrostu zagrożenia, zwłaszcza dla państw o średnim i małym potencjale militarnym. Właśnie tak broń jądrową traktuje Korea Północna. Stąd w dalszym ciągu niewielkie są postępy w kwestii nuklearnego rozbrojenia. Co więcej, nie tylko nie ,zatrzymano” samego procesu, lecz także doszło do rozbudowy potencjałów nuklearnych, zwłaszcza w państwach azjatyckich. Dlatego w dalszym ciągu wyzwaniem jest powstrzymanie proliferacji broni masowego rażenia, terroryzmu nuklearnego oraz ukierunkowanie strategii odstraszania jądrowego do wyzwań i zagrożeń, w tym działań asymetrycznych i hybrydowych.

Jak wcześniej zauważono, broń jądrowa z jednej strony stanowi gwarancje bezpieczeństwa, jest także wyznacznikiem pozycji państwa na arenie międzynarodowej, z drugiej zaś strony stanowi poważne zagrożenie dla bezpieczeństwa. Jak można pogodzić te dwie konfrontacyjne tezy? Co jest „większe”: zagrożenie czy poczucie bezpieczeństwa? Konsekwencje użycia broni jądrowej poznał cały świat po przeprowadzeniu przez Stany Zjednoczone ataków na dwa japońskie miasta - Hiroszimę i Nagasaki, w 1945 roku. Wydarzenia te nie powstrzymały nuklearyzacji świata, przeciwnie - przyśpieszyły ten proces, wywołując światowy wyścig zbrojeń w tym obszarze. Świadczy o tym liczba państw posiadających broń jądrową, nie brakuje też takich państw, których ambicją byłaby własna broń jądrowa. Nieskuteczna okazuje się też polityka nieproliferacji nuklearnej. Na oczach światowej opinii publicznej taką broń pozyskała Korea Północna, trwale destabilizując sytuację strategiczną w regionie Dalekiego Wschodu. W świetle prawa międzynarodowego aktywność państw w obszarze broni jądrowej powinna sprowadzać się przede wszystkim do:

- utrzymania stałego nadzoru nad posiadanym arsenałem nuklearnym, bez prawa przekazywania broni oraz urządzeń służących do jej produkcji;

- monitorowania polityki nuklearnej, w tym ograniczania dążenia państw nieatomowych do jej pozyskania;

- podejmowania rokowań w zakresie ograniczania wyścigu zbrojeń nuklearnych, aż do całkowitego rozbrojenia pod kontrolą międzynarodową;

- produkowania energii jądrowej tylko dla celów pokojowych.

Rozprzestrzenianiu się broni jądrowej teoretycznie sprzyja istniejący międzynarodowy stan prawny. Nie istnieją bowiem prawne ograniczenia do prowadzenia badań, rozwoju czy modernizacji posiadanych głowic jądrowych. Układ o nierozprzestrzenianiu broni jądrowej dzieli państwa na dwie grupy: państwa atomowe i nieatomowe. Pozwala to posługiwać się w polityce tezą, że istnieje pewna grupa państw uprzywilejowanych, tzw. państw atomowych, które legalnie posiadają broń jądrową, oraz pozostałe państwa, które takiej broni nie posiadają. Czy jest to trafne rozróżnienie? Właściwszy byłby podział państw według ich możliwości technologicznych. Innymi słowy, zgodnie z wymienionym traktatem, legalnymi mocarstwami atomowymi byłyby tylko USA, Rosja, Wielka Brytania, Francja, Chiny. Nie byłyby nimi już na przykład takie kraje jak Indie, Pakistan czy Izrael, bo nie są one stroną przyjętego Traktatu, jak również takie 
państwa jak Korea Północna z traktatu w 2003 roku), a także RPA, która przystąpiła do traktatu w 1992 roku, niszcząc posiadane arsenały ${ }^{10}$. Do krajów „nuklearnie podprogowych” należą państwa stojące na granicy technologii nuklearnych, pozwalających rozpocząć jej produkcję. Do tych państw należą: Argentyna, Australia, Belgia, Brazylia, Holandia, Japonia, Niemcy, Nowa Zelandia, Szwecja, Szwajcaria, Tajwan, Włochy, a także Algieria czy Korea Południowa.

Kontynuując rozważania na temat legalności posiadania broni jądrowej, można dojść do wniosku, że skoro zgodnie z prawem ww. państwa legalnie posiadają broń jądrową, to dlaczego w określonych sytuacjach nie miałyby prawa do jej użycia? Tego typu retorykę stosuje na przykład Federacja Rosyjska, która w swojej doktrynie obronnej rezerwuje sobie prawo użycia broni jądrowej w sytuacji zagrożenia swoich interesów narodowych. Rodzi się zatem pytanie: jakie okoliczności mogłyby zezwalać FR na użycie broni jądrowej? W tym obszarze toczy się spór na kanwie doktryn prawa międzynarodowego. Pewne rozstrzygnięcia daje tu opinia Międzynarodowego Trybunału Sprawiedliwości (MTS) ${ }^{11}$ z 1996 roku, wydana w związku z pytaniem Zgromadzenia Ogólnego ONZ: „Czy jest dozwolone kiedykolwiek, w myśl prawa międzynarodowego, sięgnięcie do groźby lub użycia broni jądrowej?” Na to pytanie MTS odpowiedział, że nie ma w prawie międzynarodowym jasnego zakazu - normy, która pozwalałaby, bądź bezwzględnie zakazywałaby groźby albo użycia broni nuklearnej. Przeciwne poglądy na ten temat prezentował na przykład profesor Remigiusz Bierzanek, argumentując, że skoro zakazane są możliwości używania gazów duszących lub podobnych, to już samo to jest wystarczającą przesłanką, aby uznać, że byłoby absurdem sądzić, że każda nowa broń będzie zakazana dopiero wtedy, kiedy będzie zawarta specjalna konwencja ${ }^{12}$. Wcześniej tę sprawę badało również Zgromadzenie Ogólne ONZ, przyjmując nawet stosowną rezolucję 1653/XVI/ z 1961 roku, która kwestionowała legalność użycia broni jądrowej. Nie została ona jednak przyjęta jednomyślnie. Przeciwko niej głosowały główne państwa atomowe: Francja, Wielka Brytania oraz Stany Zjednoczone ${ }^{13}$. Powstała więc sytuacja prawna tzw. niedookreśloności materialnej. Przyjmuje się zatem, że w świetle opinii MTS zakazane będzie każde użycie broni jądrowej lub tylko groźba jej użycia, jeżeli będą naruszone zasady humanitaryzmu, wynikające z IV Konwencji Haskiej z 1907 roku. Prawo nakazuje bowiem ich stosowanie przez wszystkie walczące strony. Dopuszczalne jest prowadzenie walki tylko przeciwko siłom zbrojnym przeciwnika tak, aby skutki tych działań, zwłaszcza użycia broni jądrowej, nie szkodziły ludności cywilnej. Stosuje się całkowity zakaz atakowania obiektów niebronionych lub niewojskowych. Jest to wymóg artykułu 27 Regulaminu Haskiego, który nakazuje oszczędzanie, jeżeli jest to możliwe, między innymi świątyń, szpitali, szkół, itp.,

\footnotetext{
${ }^{10}$ J. Bryła , Rozwój i znaczenie reżimów międzynarodowych na przykładzie reżimu nieproliferacji broni jądrowej, Warszawa 2006, s. 88.

${ }^{11}$ W opinii doradczej z 1996 r. Międzynarodowy Trybunał Sprawiedliwości stwierdził, że ,,ani w prawie zwyczajowym, ani w międzynarodowym prawie umów nie ma wszechstronnego i uniwersalnego zakazu groźby lub użycia broni nuklearnej jako takiej”, za: Patryk Gacka, Użycie broni nuklearnej jako zbrodnia ludobójstwa, zbrodnia przeciwko ludzkości i zbrodnia wojenna? Zarys problematyki, https://repozytorium.amu.edu.pl (20.03.2018).

${ }^{12}$ R. Bierzanek, Wojna a prawo międzynarodowe, Warszawa 1982, s. 220.

${ }^{13}$ W. Góralczyk, S. Sawicki, Prawo międzynarodowe publiczne, Warszawa 2009, s. 429.
} 
czemu nie sprzyja użycie broni jądrowej. Niedozwolone jest używanie środków walki powodujących nadmierne cierpienia ludności, a użycie broni jądrowej niewątpliwie powoduje takie skutki. Skutki wojny nie mogą dotyczyć także państw neutralnych, a broń jądrowa nie daje pewności, że tak będzie. W procesie podejmowania decyzji o użyciu broni jądrowej obowiązuje zasada proporcjonalności w odniesieniu do wyboru obiektów tak, aby zachowane zostały zasady „koszt ludzki - efekt militarny”. Prawo wprowadza także obowiązek powstrzymania się od stosowania groźby lub użycia siły przeciwko terytorium lub niepodległości któregokolwiek państwa ${ }^{14}$.

Zasady te wyprowadzone zostały wprost $\mathrm{z}$ międzynarodowego prawa humanitarnego konfliktów zbrojnych, a zatem obowiązują wszystkie strony konfliktu. Niemniej jednak może zaistnieć taki stan faktyczny, który będzie stanowił pewną nadzwyczajną okoliczność usprawiedliwiającą użycie broni jądrowej (na przykład zagrożenie istnienia państwa, zmuszające je okolicznościami do skorzystania z prawa do samoobrony przy użyciu wszystkich dostępnych środków). Warto dodać, że prawo do samoobrony wynika wprost z artykułu 51 Karty Narodów Zjednoczonych, który dotyczy zarówno samoobrony indywidualnej, jak i zbiorowej. Zapis ten pozwala, czy raczej umożliwia obronę państwa, które nie dysponuje bronią jądrową, przez państwa, które taką broń posiadają. Na tych przesłankach opiera się polityka jądrowa NATO.

\section{DOŚWIADCZENIA HISTORYCZNE}

Broń jądrowa wywarła ogromny wpływ na charakter stosunków międzynarodowych. Po pierwsze, przyczyniła się do zakończenia II wojny światowej w Azji, a po drugie, w okresie „zimnej wojny” dawała gwarancje bezpieczeństwa państwom Europy Zachodniej. Stąd też tak wiele państw dążyło i dąży do jej posiadania, postrzegając swój arsenał jako tani środek militarny, tańszy niż rozbudowa sił konwencjonalnych, do uzyskania porównywalnego poziomu odstraszania i potencjalnych skutków rażenia.

W okresie II wojny światowej zarówno Niemcy hitlerowskie, jak i Stany Zjednoczone prowadziły intensywne badania nad skonstruowaniem bomby atomowej. Trwał swoisty wyścig z czasem, który doprowadził Stany Zjednoczone w ramach programu Manhattan do skonstruowania pierwszej na świecie bomby atomowej. Jej udane testy przeprowadzono 16 lipca 1945 roku, ale już 6 sierpnia wykorzystano ją przeciwko Japonii, bombardując Hiroszimę, a następnie Nagasaki (trzy dni później - 9 sierpnia). Można się zastanawiać, czy konieczne były dwa ataki, czy miały one podłoże wojskowe, czy raczej była to polityczna demonstracja siły, służąca zastraszeniu Związku Radzieckiego. Można też spekulować, co by się stało, gdyby to Niemcy pierwsi skonstruowali broń jądrową? Można oczywiście z dużą dozą prawdopodobieństwa przyjąć, że użyliby tej broni w końcowej fazie wojny przeciwko aliantom lub ZSRR. Kwestią otwartą byłby tylko wybór obiektów ataku, który wywołałby

\footnotetext{
${ }^{14}$ Konwencja dotycząca praw $i$ zwyczajów wojny lądowej, Haga, 18 października 1907 r. oraz Załącznik do konwencji: Regulamin dotyczacy praw i zwyczajów wojny lądowej, Haga, 18 października 1907 r. ( Dz. U. z 1927r., nr 21, poz. 161 ).
} 
porównywalny, z pewnością nawet większy szok, który zmusiłby sojuszników do negocjacji.

Bomby atomowe zrzucone na japońskie miasta potwierdziły swoją niszczycielską moc. Stały się więc obiektem pożądania, co uruchomiło serię programów nuklearnych w różnych państwach. Najbardziej zaawansowany w tym wyścigu był Związek Radziecki, który już w 1949 roku przeprowadził pierwszą udaną próbę atomową. Stał się tym samym drugim państwem atomowym na świecie. W 1952 roku do „klubu państw nuklearnych” dołączyła Wielka Brytania, a w 1960 roku Francja. W 1964 roku do tej grupy dołączyły także Chiny. W toku dalszych prac nad rozwojem broni atomowej w 1952 roku opracowano broń termojądrową (wodorową), a w dalszej kolejności w 1962 roku skonstruowano broń neutronową. Przemysł jądrowy ruszył więc na dobre. Pracowano nad zmniejszeniem ciężaru i wymiarów bomb jądrowych tak, aby mogły je przenosić strategiczne samoloty bombowe. Intensywnie pracowano nad miniaturyzacją głowic jądrowych, przystosowując je do zamontowania w rakietach balistycznych, minach oraz w pociskach artyleryjskich. Tego procesu nie udało się już zatrzymać ${ }^{15}$.

Wyścig zbrojeń, który został zapoczątkowany w latach 60. XX wieku stanowił jeden z głównych elementów ,zimnej wojny”. Rozwijano programy zbrojeniowe, których celem była produkcja rakiet międzykontynentalnych, rakiet balistycznych bazowania lądowego i morskiego oraz rakiet taktycznych. Rozpoczął się także proces rozmieszczania amerykańskiej taktycznej broni jądrowej w Europie. Działania te służyły ewentualnemu wykorzystaniu broni jądrowej podczas następnego konfliktu ogólnoświatowego, jeżeli taki by zaistniał. Broń jądrowa miała także służyć poprawie bezpieczeństwa Stanów Zjednoczonych oraz sojuszniczych krajów NATO.

Olbrzymia siła niszczycielska broni jądrowej, a także szybki rozwój techniki wojennej doprowadziły do zmian w strategii, taktyce i organizacji wojsk. W zasadniczy sposób zmieniły się też poglądy na charakter przyszłej wojny. Warto jednak zauważyć, że rosnąca popularność broni jądrowej nie przyćmiła roli wojsk lądowych oraz broni konwencjonalnej. Pojawiły się głosy, że sama broń atomowa nie będzie mogła skutecznie rozstrzygnąć przebiegu wojny. W ostatecznym rozrachunku przyjmowano, że do całkowitego rozgromienia przeciwnika, a także opanowania jego terytorium, konieczne są konwencjonalne siły lądowe. Dlatego broń jądrową postrzegano tylko w powiązaniu z użyciem sił konwencjonalnych (powietrznych, morskich i lądowych).

W latach 60. między USA a ZSRR ukształtowała się tzw. „równowaga strachu” oparta na zrównoważonym potencjale jądrowym, a tym samym broń jądrowa stała się głównym środkiem odstraszania. Negatywnym następstwem tej równowagi był ciągły wyścig zbrojeń, który przyczyniał się do rozwijania nowych sił i środków w ramach wprowadzanych nowych koncepcji strategicznych. Oczywiście pierwszoplanową rolę odgrywała broń jądrowa i jej środki przenoszenia, czego wyrazem było sformułowanie strategii odstraszania opartej na prostych zasadach, według których należało utworzyć odpowiedni arsenał broni jądrowej

\footnotetext{
${ }^{15}$ K. Lenartowicz, M.Radomski, Rozwój oraz budowa broni jądrowej i termojądrowej w XX wieku, Warszawa 2014, wyd. online: http://www.if.pw.edu.pl/ (10.09.2019).
} 
równy lub - jeszcze lepiej - przewyższający możliwości przeciwnika ${ }^{16}$. Posiadany arsenał jądrowy wzmacniał nie tylko pozycję mocarstwa na arenie międzynarodowej, kreował politykę bezpieczeństwa, lecz także dzięki mocy posiadanych ładunków jądrowych mógł zniszczyć przeciwnika. W tym okresie stratedzy wojskowi zdawali sobie jednak sprawę, że przewaga w posiadaniu broni jądrowej traci powoli na znaczeniu, a przewaga Stanów Zjednoczonych ulegnie zmniejszeniu, gdyż ZSRR powoli, lecz skutecznie równoważył swój potencjał z potencjałem nuklearnym USA. Tym niemniej w ówczesnym okresie panował pogląd, że broń jądrowa jest niezbędnym elementem zniwelowania przewagi Układu Warszawskiego w konwencjonalnych siłach zbrojnych i rodzajach uzbrojenia.

W latach 70. doszło do chwilowego odprężenia w stosunkach między USA a ZSRR, czego skutkiem była próba budowania środków zaufania, mających na celu stworzenie skutecznego systemu bezpieczeństwa międzynarodowego. W 1968 roku podpisano „Traktat o nieproliferacji broni jądrowej NPT”, który był milowym krokiem w budowaniu wzajemnego zaufania, zobowiązując państwa sygnatariuszy do nieprzekazywania i niepomagania innym państwom w planach pozyskania broni jądrowej. W następnych latach kontynuowano rozmowy bilateralne, czego efektem było podpisanie ważnych układów międzynarodowych, dotyczących kontroli, ograniczenia i redukcji strategicznych zbrojeń. Wyrazem tego odprężenia była Konferencja Bezpieczeństwa i Współpracy w Europie w 1973 roku oraz przyjęcie Aktu Końcowego z Helsinek w dniu 1 sierpnia 1975 roku.

W wyniku rozpadu systemu dwubiegunowego na początku lat 90. znacznie zmalało prawdopodobieństwo wybuchu konfliktu zbrojnego na dużą skalę z użyciem broni jądrowej. Państwa nie zrezygnowały jednak z rozbudowy swoich arsenałów jądrowych. Po zakończeniu „zimnej wojny” rola broni jądrowej jako środka odstraszania przestała odpowiadać nowym realiom. Poprzednio zarówno Stany Zjednoczone, jak i ZSRR broń jądrową traktowały jako szczególną szansę na światową dominację. Stany Zjednoczone postrzegały także broń jądrową jako przeciwwagę dla radzieckich sił konwencjonalnych rozmieszczonych w krajach Europy Wschodniej oraz jako środek wyhamowywania jej ekspansjonistycznych planów. Na przestrzeni wielu lat bezpieczeństwo i strategia wojenna państw zachodnich opierały się głównie na odstraszającej roli broni jądrowej i możliwości jej użycia. Zakładano jednak, że każda próba użycia broni jądrowej natychmiast spowoduje działania odwetowe, co doprowadziłoby do długotrwałej, nieograniczonej, totalnej wojny atomowej, która - oprócz straszliwych zniszczeń po obydwu stronach konfliktu - przyniosłaby zagładę milionom istnień ludzkich. Oczywiście pojawiło się pytanie, kto wygrałby tę wojnę? Straty zwycięzcy w wojnie jądrowej mogły okazać się tak wielkie, że wątpliwe byłoby wykorzystanie tego zwycięstwa. Stawiano pytanie, czy użycie broni jądrowej jest jedynym środkiem osiągnięcia celu, gdyż

\footnotetext{
${ }^{16}$ Doktryna odstraszania to termin wywodzący się okresu zimnej wojny o charakterze politycznym oraz wojskowym, zakładający, że proporcjonalne zwiększenie zasobów militarnych oraz potencjału wojskowego spowoduje rezygnację przeciwnika w kwestii rozpoczęcia ewentualnych działań zbrojnych, za: S. Zarychta, Doktryny i strategie NATO 1945-2012, Gdynia 2012, s. 145.
} 
żaden $\mathrm{z}$ celów wojny nie wydawał się tak ważny, aby ryzykować zniszczenie ludności i obrócenie w gruzy własnego kraju.

\section{PERSPEKTYWY WYKORZYSTANIA BRONI JĄDROWEJ W POLITYCE BEZPIECZEŃSTWA WYBRANYCH PAŃSTW}

Kraje dysponujące bronią jądrową bardzo intensywnie modernizują swoje arsenały. W obecnych realiach geopolitycznych trudno wyobrazić sobie, aby była możliwa ich redukcja. Innymi słowy, wizja świata bez broni jądrowej praktycznie się oddala. Raczej nie powtórzy się sukces z lat 90. XX wieku, kiedy z powodzeniem realizowano programy rozbrojeniowe Stanów Zjednoczonych i Rosji, które doprowadziły do ograniczenia liczby głowic strategicznych (Start I i II ${ }^{17}$ ), a także redukcji taktycznej broni jądrowej w Europie. Działania te objęły także francuskie i brytyjskie potencjały jądrowe. Po upadku Związku Radzieckiego posiadania broni atomowej dobrowolnie zrzekły się Ukraina, Białoruś i Kazachstan. Zakończył się także program jądrowy RPA, a potencjał jądrowy zlikwidowano.

Można przyjać, że sukces rozbrojeniowy dał znaczący impuls przywódcom USA i Rosji do formułowania politycznych deklaracji o możliwości całkowitego wycofania broni jądrowej i uznania jej za przeszłość, swoisty relikt, jaki pozostał po okresie zimnowojennym, nijak niepasujący do współczesnych realiów geopolitycznych. W Europie odnotowywano sukcesy rozbrojeniowe. Natomiast na Dalekim Wschodzie już w 1998 roku rozpoczął się atomowy wyścig. W 2003 roku z układu o nierozprzestrzenianiu broni jądrowej wycofała się Korea Północna. W tym samym czasie prace nad bronią jądrową kontynuował też Iran. Utrudniało to prace nad globalnym rozbrojeniem. Nie bez winy były również Stany Zjednoczone, które w 2001 roku jednostronnie wycofały się z traktatu o ograniczeniu systemów antybalistycznych (Anti-Ballistic Missile Treaty - traktat ABM). W takim czasie, trudnym geopolitycznie, pojawiła się wizja świata bez broni jądrowej przedstawiona przez Baracka Obamę najpierw w Berlinie, w lipcu 2008 roku, a następnie w kwietniu 2009 roku w Pradze, przy okazji obchodów 60-lecia NATO. Jak się ocenia, te plany były jedną z głównych przyczyn, dla których Barack Obama już jako Prezydent otrzymał Pokojową Nagrodę Nobla. Zmieniło to jego pozycję negocjacyjną, pozwoliło także doprowadzić do finału rozmowy w sprawie traktatu New Start, podpisanego z Rosją w kwietniu 2010 roku w Pradze. Traktat ograniczył liczbę strategicznych głowic jądrowych do 1550 po każdej ze stron. W zasadzie był to koniec sukcesów rozbrojeniowych. W sprawie redukcji rakiet taktycznych rozmów nawet nie podjęto. Głównym powodem był brak zainteresowania ze strony Federacji Rosyjskiej. Mimo powściągliwej reakcji Rosji na dalsze rozbrojenie nuklearne, Stany Zjednoczone samodzielnie wycofały ze służby rakiety Tomahawk, uzbrojone w głowice jądrowe, pozbawiając swoją marynarkę wojenną taktycznej broni jądrowej. Prezydent Stanów Zjednoczonych jednostronnie

\footnotetext{
${ }^{17}$ Strategic Arms Reduction Treaty (START II) - drugi traktat START o redukcji zbrojeń strategicznych (pierwszym był START I, zawarty 31 lipca 1991 r.), podpisany w Moskwie 3 stycznia 1993 r. przez prezydenta Stanów Zjednoczonych, George'a Busha Seniora, i prezydenta Rosji, Borysa Jelcyna.
} 
zapowiedział dalsze ograniczenie liczby strategicznych głowic jądrowych do 1000-1100 w perspektywie do 2023 roku. Plany te potwierdzono w „Strategii użycia broni nuklearnej” (Nuclear Weapons Employment Strategy) z 2013 roku. Co z tego zostało? Niewiele. Wszystkie państwa dysponujące bronią jądrową inwestują w jej modernizację oraz unowocześnianie środków przenoszenia. Żadne z mocarstw atomowych, za wyjątkiem Stanów Zjednoczonych, nie zapowiada redukcji tej broni.

Zaawansowane plany rozbudowy potencjału nuklearnego Stanów Zjednoczonych obejmują w pierwszej kolejności lotnictwo. Planuje się wprowadzenie do służby, ok. 2024 roku, nowego bombowca strategicznego LRS-B (Long Range Strategic Bomber), który będzie sukcesywnie zastępować B-52H i B-1B. W sumie planuje się wprowadzenie ok. 80-100 samolotów ${ }^{18}$. Nowe maszyny mogą być bezzałogowe, co zapewne wywoła dyskusję nad możliwością uzbrojenia w broń jądrową tego typu samolotów. Amerykanie prowadzą też prace studyjne nad nową kategorią rakiet balistycznych. Nowe pociski miałyby wejść do służby pod koniec trzeciej dekady, w wersjach stacjonarnych i mobilnych, miedzy innymi przeznaczonych dla okrętów podwodnych. Plany dotyczą także rozbudowy obrony przeciwrakietowej, bo istniejący system nie jest w stanie odeprzeć zmasowanego uderzenia jądrowego, co otwarcie przyznają amerykańskie władze.

Polityka rozbrojenia nuklearnego Stanów Zjednoczonych jest konfrontowana z rosnącymi wydatkami na broń atomową w Chinach, a przede wszystkim w Federacji Rosyjskiej, której budżet zbrojeniowy zbliża się do $14 \% \mathrm{PKB}^{19}$. W tej sytuacji nie należy chyba oczekiwać kolejnego kroku rozbrojeniowego ze strony USA. Stany Zjednoczone w ramach ustaleń traktatu New Start zredukowały swój potencjał strategicznych głowic nuklearnych do założonego poziomu w 2018 roku $^{20}$. Jak oceniają eksperci, efekt jest taki, że Stany Zjednoczone po raz pierwszy od wielu lat utraciły przewagę w liczbie posiadanych strategicznych głowic atomowych. Rosja od dawna dysponuje kilkukrotną przewagą nad arsenałem amerykańskim, który tworzą przede wszystkim lotnicze bomby jądrowe B-61, modernizowane do standardu bomby precyzyjnej. Stany Zjednoczone idą więc na jakość, nie na ilość. Do roli nosicieli przygotowuje się samoloty bojowe piątej generacji (F-35), opracowane $\mathrm{w}$ technologii stealth, które - jak się zakłada - osiągną gotowość do przeprowadzania uderzeń jądrowych około 2024 roku. Zmodernizowane bomby B-61 prawdopodobnie będą udostępniane także europejskim członkom NATO w ramach programu Nuclear Sharing.

\footnotetext{
${ }^{18}$ Sekretarz sił powietrznych USA Deborah Lee James oficjalnie ogłosiła pełną nazwę nowego bombowca strategicznego powstającego w ramach programu Long Range Strike-Bomber (LRS-B), za: Northrop Grumman B-21 Raider, http://www.nowastrategia.org.pl (21.03.2018).

19 SIPRI Yearbook 2018: Armaments, Disarmament and International Security, 6. World nuclear forces, https://www.sipri.org/ (28.10.2019).

$20 * * *$ Po tym jak Stany Zjednoczone (a potem Rosja) zawiesiły obowiązywanie traktatu INF, w przestrzeni publicznej pojawiły się pytania o układ New START, który zakłada ograniczenie strategicznych zbrojeń nuklearnych. Jeśli nie zostanie on przedłużony, umowa między dwoma mocarstwami wygaśnie 5 lutego 2021 roku. Stany Zjednoczone zapowiedziały, że decyzja w sprawie New START zapadnie dopiero w 2020 roku. Ocenia się, że podobnie jak w przypadku Traktatu INF, w tej sprawie Stanom Zjednoczonym także bardziej chodzi o Chiny i gra między USA a Rosją ma charakter pozorny, za: New START: USA, Rosja i Chiny. Czy czeka nas nowy wyścig zbrojeń, http://www.polska-zbrojna.pl/, (8.09.2019).
} 
Intensywne zbrojenia prowadzi także Federacja Rosyjska, która planuje przywrócić produkcję bombowców strategicznych $\mathrm{Tu}-160 \mathrm{w}$ nowej wersji, uruchomiła także prace nad nowym bombowcem PAK-DA, którego uzbrojenie mają stanowić samosterujące rakiety o napędzie hipersonicznym ${ }^{21}$. Trwa modernizacja sił rakietowych. Do służby wprowadzane są nowe systemy RS-24 Jars oraz RS-26 Rubież. Równolegle trwają prace nad nowym, ciężkim, ważącym ponad 100 ton pociskiem RS-28 Sarmat. Nowa rakieta, która wejdzie do służby w trzeciej dekadzie XXI wieku, będzie mieć możliwość przenoszenia do 15 głowic oraz przelotu nad Biegunem Południowym, co umożliwi zaatakowanie USA z kierunku, na którym nie dysponują one rozbudowanymi systemami przeciwrakietowymi. Rosyjska marynarka wojenna po 2030 roku planuje wprowadzenie do służby piątej generacji okrętów podwodnych, uzbrojonych w rakiety R-30 Buława (morska wersja pocisków Topol-M) ${ }^{22}$.

Rosja nie zaniedbuje także taktycznej broni jądrowej. Nie waha się nawet przed łamaniem traktatu INF z 1987 roku o likwidacji rakiet średniego i pośredniego zasięgu ${ }^{23}$. Chodzi o rozmieszczanie w rejonie Kaliningradu oraz rejonie Morza Kaspijskiego rakiet manewrujących Kalibr-NK, o zasięgu nawet ponad $2500 \mathrm{~km}$, oraz rakiet Iskander-K z rakietą manewrującą R500 o zasięgu ok. $2000 \mathrm{~km}$. Rosyjska marynarka wojenna - poza zdolnymi do przenoszenia broni jądrowej rakietami Kalibr-NK, których użyto podczas wojny w Syrii - pracuje też nad rakietami przeciwokrętowymi P-900 Alfa ${ }^{24}$. Testowana jest wersja kontenerowa tych rakiet, możliwa do rozmieszczenia np. na statkach cywilnych. Należy się zatem zastanowić, czy taktyczna rosyjska broń jądrowa to tylko straszak, czy całkiem realne zagrożenie dla NATO.

Planom tym nie ustępuje Chińska Republika Ludowa, dysponująca trzecim na świecie arsenałem jądrowym. Modernizacja jądrowego potencjału Chin przebiega jednak w sposób bardziej skryty. Najważniejszym chińskim programem rozwojowym są rakiety balistyczne DF-41 o zasięgu około $15000 \mathrm{~km}$. Ich uzbrojenie stanowi głowica termojądrowa o mocy $1 \mathrm{Mt}$, albo do 10 głowic MIRV (Multiple Independently Targetable Reentry Vehicle), albo głowice niezależnie wcelowywane o regulowanej mocy wybuchu pomiędzy 20 a $250 \mathrm{kt}$. Chińskie lotnictwo planuje ok. 2025 roku wprowadzić do służby nowej generacji bombowiec strategiczny Xian H-20. Według dostępnych, niepotwierdzonych informacji, może być odpowiednikiem amerykańskiego B--2. Modernizuje się także marynarka wojenna, która w najbliższych latach planuje wprowadzenie rakiet balistycznych drugiej generacji, o zasięgu do $8000 \mathrm{~km}$, zdolnych do przenoszenia pojedynczej głowicy jądrowej lub 3-4 głowic MIRV. W rakiety te, w ilości ośmiu sztuk, wyposażane będą nowo wprowadzane okręty podwodne.

\footnotetext{
21 J. Bartosiak, R. Lipka, K. Zięć, Następne 25 lat" - Siły Powietrzne RP w koncepcji prowadzenia wojny powietrznolądowej w Europie Środkowo-Wschodniej, https://pulaski.pl/, s. 10 i n., (15.09.2019), Vide: także: Lotnictwo wojskowe, Przemysł zbrojeniowy: https://www.altair.com.pl/news/view?news_id=16964.

${ }^{22}$ Za: http://www.altair.com.pl, dostęp: 14.05.2015 rok., Vide także: Program modernizacji Sił Zbrojnych Federacji Rosyjskiej - stan realizacji i perspektywy powodzenia, https://pulaski.pl/wp-content/uploads/2015/02/ Komentarz_Miedzynarodowy_Pulaskiego_nr_02_15_PL.pdf

${ }^{23}$ Rosjanie złamali układ INF o likwidacji pocisków rakietowych średniego zasięgu z 1987 roku rozmieszczając na swoim terytorium rakiety manewrujące o zasięgu większym niż $500 \mathrm{~km}$, http://www.defence24.pl, (12.12.2017).

${ }^{24}$ A. Hładyij, Koniec iluzji świata bez broni jądrowej. Trwa modernizacja arsenałów, https://www.space24.pl/konieciluzji-swiata-bez-broni-jadrowej-trwa-modernizacja-arsenalow (10.11.2019).
} 
Chiny pracują również nad pociskami nowej generacji dla wojsk lądowych. Mają one charakteryzować się obniżoną skuteczną powierzchnią odbicia oraz dysponować zasięgiem nawet do $4000 \mathrm{~km}^{25}$.

\begin{tabular}{|l|l|c|c|c|c|}
\hline Lp. & Państwo & $\begin{array}{l}\text { Pierwszy } \\
\text { test }\end{array}$ & $\begin{array}{l}\text { Rozmieszczone } \\
\text { głowice * }\end{array}$ & $\begin{array}{l}\text { Pozostałe } \\
\text { głowice ** }\end{array}$ & Ogółem \\
\hline 1. & USA & 1945 & 1800 & 5000 & 6800 \\
\hline 2. & Federacja Rosyjska & 1949 & 1950 & 5050 & 7000 \\
\hline 3. & Wielka Brytania & 1952 & 120 & 95 & 215 \\
\hline 4. & Francja & 1960 & 280 & 20 & 300 \\
\hline 5. & Chiny & 1964 & & 270 & 270 \\
\hline 6. & Indie & 1974 & & $120-130$ & $120-130$ \\
\hline 7. & Pakistan & 1998 & & $130-140$ & $130-140$ \\
\hline 8. & Izrael & & & 80 & 80 \\
\hline 9. & Korea Północna & 2006 & & $10-20$ & $10-20$ \\
\hline \multicolumn{2}{|l|}{ Razem } & & 4150 & 10785 & 14935 \\
\hline
\end{tabular}

Tabela1. Potencjał jądrowy różnych państw na świecie (stan z lipca 2017 rok)

Źródło: opracowanie własne na podstawie SIPRI Fact Sheet, Trends in world nuclear forces, 2017 https://www.sipri.org, (12.03.2019).

\footnotetext{
* Rozmieszczone głowice to te, które są umieszczone na pociskach lub znajdują się w bazach sił operacyjnych.

** Inne głowice to te, które są przechowywane, wycofane lub oczekują na demontaż.
}

Spośród państw posiadających potencjał jądrowy na uwagę zasługuję jednak Korea Północna, która bardzo intensywnie pracuje nad rakietami balistycznymi średniego i dalekiego zasięgu. Podstawą technologiczną budowy rakiet balistycznych średniego zasięgu prawdopodobnie są rakiety oparte na technologii radzieckiej z lat sześćdziesiątych, zdolne razić cele na odległość do $4000 \mathrm{~km}^{26}$.

Według propagandy reżimu Kim Dzong Una kraj ten dysponuje już rakietami zdolnymi do rażenia celów w USA. Jest to jednak, przynajmniej na ten moment, mało prawdopodobne, ale po udanych testach w 2017 roku z rakietami Hawasong 15, wkrótce może się okazać całkiem realne ${ }^{27}$.

Za sukces społeczności międzynarodowej można uznać zawarcie w 2015 roku porozumienia jądrowego z Iranem, który w zamian za zniesienie sankcji zgodził się na zawieszenie swojego programu budowy broni atomowej. Porozumienie to nie przetrwało próby czasu, bo w 2018 roku zostało wypowiedziane przez Prezydenta Stanów Zjednoczonych Donalda Trumpa. Impas w relacjach Stany Zjednoczone - Iran trwa. Wycofanie się nowej administracji w Waszyngtonie z porozumienia atomowego $\mathrm{z}$ Teheranem, mimo krytyki tego kroku ze strony europejskich partnerów, obrazuje obecny stan relacji transatlantyckich ${ }^{28}$. Na razie nie widać innych państw, które za wszelką cenę chciałyby rozwijać technologię jądrową. Należy jednak zauważyć, że jest to konsekwencja działań politycznych, a nie barier technologicznych. Dla wielu państw, takich jak Niemcy, Japonia, Korea Południowa czy Australia, zbudowanie własnej bomby

\footnotetext{
${ }^{25} \mathrm{Za}$ : https://www.defence24.pl/nowy-chinski-bombowiec-strategiczny (26.10.2019).

${ }^{26} \mathrm{Za}$ : http://www.psz.pl/124-polityka/ocena-zagrozenia-ze-strony-polnocnokoreanskiego-programu-rakietowego (10.11.2019).

${ }^{27} \mathrm{Za}$ : portal https://www.tvn24.pl (20.01.2018).

${ }^{28} \mathrm{Za}:$ https://ec.europa.eu/poland/news/181023_porozumienie_pl,(18.11.2019).
} 
jądrowej to kwestia kilku miesięcy. Dlatego też wizja świata bez broni jądrowej pozostaje wciąż tylko iluzją (Stan sił jądrowych - vide tabela nr 1).

\section{Podsumowanie}

Przeprowadzone analizy wskazują, że broń jądrowa była, jest i nadal będzie ważnym czynnikiem odstraszania. Skonstruowanie broni jądrowej zrewolucjonizowało zasady oraz sposoby prowadzenia działań wojennych. Jej użycie wpłynęło na treści doktryn, koncepcje użycia sił zbrojnych, a także zapewniły ciągły rozwój struktur oraz wyposażenia sił zbrojnych. Broń jądrowa, ze względu na swą niszczycielską siłę, odgrywa główną rolę w polityce odstraszania, jest także głównym środkiem utrzymania bezpieczeństwa. W okresie ,zimnej wojny” stanowiła ważny element strategii równowagi sił NATO i Układu Warszawskiego, wykorzystując tzw. „doktrynę strachu”. Strach przed skutkami jej zmasowanego użycia zapewnił na wiele dziesięcioleci stabilność dwubiegunowego układu sił. Podpisane traktaty i umowy rozbrojeniowe były krokiem na przód, mającym na celu zarówno zwiększanie bezpieczeństwa międzynarodowego, w kontekście wyzwań globalnych, jak i przeciwdziałanie proliferacji broni jądrowej. Działania te nie były jednak do końca skuteczne, z czego współcześnie politycy oraz eksperci wojskowi zdają sobie sprawę. Nie ma woli we współczesnym świecie, aby zrezygnować $\mathrm{z}$ broni jądrowej. Przeciwnie, istnieją państwa, które chcą taką broń pozyskać. Mimo prowadzonych rozmów dotyczących redukcji zbrojeń, największym wyzwaniem dla współczesnego świata pozostaje terroryzm jądrowy i proliferacja broni masowego rażenia, w tym broni jądrowej. Nie ma też większej różnicy w doktrynalnym postrzeganiu broni jądrowej wśród tzw. państw atomowych, co oznacza, że broń jądrowa jest jednakowo ważnym elementem bezpieczeństwa dla Stanów Zjednoczonych, jak i Federacji Rosyjskiej.

\section{BIBLIOGRAFIA}

Bierzanek Remigiusz. 1982. Wojna a prawo międzynarodowe. Warszawa: Wyd. MON.

Bryła Jolanta. 2006. Rozwój i znaczenie reżimów międzynarodowych na przykładzie reżimu nieproliferacji broni jądrowej. Warszawa.Wyd. SCHOLAR.

Dura Maksymilian, 2017, Koniec zimnowojennego traktatu INF. Amerykanie przyznają, że Rosja rozmieszcza zakazane rakiety. http://www.defence24.pl.

Dura Maksymilian. 2019. Nowy chiński bombowiec strategiczny. Hawaje w zasięgu uderzenia, https://www.defence24.pl/nowy-chinski-bombowiec-strategiczny.

Frymark Kamil, 2019, Porozumienie nuklearne z Iranem: perspektywa europejska, https://ec.europa.eu/poland/news/181023_porozumienie_pl.

Gacka Patryk, 2015, Użycie broni nuklearnej jako zbrodnia ludobójstwa, zbrodnia przeciwko ludzkości i zbrodnia wojenna? Zarys problematyki, https://repozytorium.amu.edu.pl.

Góralczyk Wojciech, Sawicki Stefan. 2009. Prawo międzynarodowe publiczne. Warszawa: Wyd. Lexsis Nexis. 
Hładij Andrzej. 2014. Memorandum Budapesztańskie - pozorna gwarancja bezpieczeństwa dla Ukrainy, https://www.defence24.pl/memorandum-budapesztanskie-pozorna-gwarancjabezpieczenstwa-dla-ukrainy.

Hładij Andrzej/ 2019. NATO Nuclear Sharing - sposób na wzmocnienie polskiego potencjału obronnego, http://www.defence24.pl/analiza_nato-nuclear-sharing-sposobna-wzmocnieniepolskiego-potencjalu-obronnego

Hładyij Andrzej. Koniec iluzji świata bez broni jądrowej. „Trwa modernizacja arsenałów”, https://www.space24.pl/koniec-iluzji-swiata-bez-broni-jadrowej-trwa-modernizacjaarsenalow.

Informacja redakcyjna. 2018. Missile Defense Project, Hwasong-15 (KN-22), Missile Threat, Center for Strategic and International Studies, www.independent.co.uk/us.

Informacje redakcyjne. 2019. Iran już gotowy na bombę atomową, http://wgospodarce.pl/informacje/62980-iran-juz-gotowy-na-bombe-atomowa.

Kacprzyk Artur. 2019. Koniec traktatu INF. http://www.pism.pl/publikacje/komentarz/nr-10-2019.

Kimball Daryl. 2019. The Intermediate-Range Nuclear Forces (INF) Treaty at a Glance, https://www.armscontrol.org/factsheets/INFtreaty.

Konwencja dotycząca praw i zwyczajów wojny lądowej, Haga, 18 października 1907 roku oraz Załącznik do konwencji: Regulamin dotyczący praw i zwyczajów wojny lądowej, Haga, 18 października 1907 r. ( Dz. U. z 1927r., nr 21, poz. 161 ).

Lenartowicz Krzysztof, Radomski Mateusz. 2014. Rozwój oraz budowa broni jądrowej i termojądrowej w XX wieku, Warszawa: Wyd. Politechnika Warszawska, http://www.if.pw.edu.pl/.

Memorandum budapeszteńskie (Memorandum Budapeszteńskie o Gwarancjach Bezpieczeństwa), https://pl.wikipedia.org/wiki/Memorandum_budapeszteńskie.

Muczyński Rafał. 2016. Northrop Grumman B-21 Raider, http://www.nowastrategia.org.pl.

Peace Research Institute. 2016. SIPRI Yearbook 2018: Armaments, Disarmament and International Security, 6. World nuclear forces, https://www.sipri.org/.

Portal informacyjny. 2014. Strategic Arms Reductions. Problems, events, analysis, http://www.armscontrol.ru/start/.

Portal Spraw Zagranicznych, opracowanie redakcyjne. 2018. Ocena zagrożenia ze strony północnokoreańskiego programu rakietowego. http://www.psz.p1/124-polityka/ocenazagrozenia-ze-strony-polnocnokoreanskiego-programu-rakietowego.

Rybczyński Wojciech. 2018. Rosja gotowa do wojny nuklearnej. Putin straszy świat, www.geopolityka.org.

Sherman Robert. 2002. Strategic Arms Reduction Treaty (START II), https://fas.org/ nuke/control/start2/.

Smura Tomasz, Lipka Rafał. 2015. Komentarz Międzynarodowy Pułaskiego nr 02/15, Program modernizacji Sił Zbrojnych Federacji Rosyjskiej - stan realizacji i perspektywy powodzenia, https://pulaski.pl/wp.

Wiadomość redakcyjna. 2016. Debiut rakiety balistycznej „Sarmat”. http://www.space24.pl. Wołejko Piotr. 2019. Proliferacja - niedocenione zagrożeniehttp://www.politykaglobalna.pl. Zarychta Stanisław. 2012. Doktryny i strategie NATO 1945 - 2012. Gdynia: Wyd. AMW. Zarychta Stanisław. 2016. Broń jądrowa w kształtowaniu bezpieczeństwa 1945-2015. Warszawa: wyd. Bellona. 